\title{
Influence of Different Vegetable Oils on In Vitro Ruminal Fermentability and Nutrient Digestibility in Ettawah Crossbred Goat
}

\author{
Anis Muktiani*, Nurul Arifah and Widiyanto \\ Faculty of Animal and Agriculture Science, Diponegoro University, Semarang, Indonesia \\ *Corresponding author email: anismuktiani@live.undip.ac.id
}

\begin{abstract}
This research was aimed to determine the effect of supplementation of vegetable oil (corn oil, palm oil and kapok seed oil) on in vitro ruminal fermentability and nutrient digestibility. Experiment design used was Randomized Block Design with four treatments and four replicates according to rumen fluid sampling time. The four treatments were R0 $=$ feed without oil supplementation; R1 = R0 + 5\% corn oil; R2 = R0 + 5\% palm oil; and $\mathrm{R} 3=\mathrm{R} 0+5 \%$ kapok seed oil. The result showed that supplementation of $5 \%$ vegetable oil did not affect the rumen $\mathrm{pH}, \mathrm{A} / \mathrm{P}$ ratio, and the efficiency of energy conversion. Compared to control, the $5 \%$ supplement increased total VFA, acetate, propionate, butyrate, methane and $\mathrm{NH}_{3}$. However, the $5 \%$ supplement resulted in a lower protozoa population, microbial protein, in vitro dry matter digestibility (IVDMD), organic matter digestibility (IVOMD), and crude fiber digestibility (IVCFD) than those of control. Population of protozoa decreasfed until $58.76 \%$ for R1; $66.89 \%$ for R2; and $43.33 \%$ for R3. It can be concluded that $5 \%$ vegetable oil supplementation decreased protozoa population but increased the production of VFA and $\mathrm{NH}_{3} .5 \%$ kapok seed oil produced the highest of total VFA, acetate, propionate, butyrate and $\mathrm{NH}_{3}$ among other treatments.
\end{abstract}

Keywords: ruminal fermentability, vegetable oil, nutrient digestibility, in vitro

Abstrak. Penelitian ini bertujuan untuk mengkaji efek penambahan minyak nabati (minyak jagung, minyak kelapa sawit dan minyak biji kapuk) terhadap fermentabilitas rumen dan kecernaan nutrien secara in vitro. Rancangan yang digunakan yaitu Rancangan Acak Kelompok dengan empat perlakuan dan empat ulangan berdasarkan waktu pengambilan cairan rumen. Empat perlakuan yang dicobakan yaitu RO = Tanpa suplementasi minyak; R1 = R0 + 5\% minyak jagung; R2 = R0 + 5\% minyak kelapa sawit, dan $R 3=R 0+5 \%$ minyak biji kapuk. Hasil penelitian menunjukkan bahwa penambahan $5 \%$ minyak nabati tidak berpengaruh terhadap $\mathrm{pH}$ rumen, rasio $\mathrm{A} / \mathrm{P}$, dan efisiensi konversi energi. Total VFA, produksi asetat, propionat, butirat, methan, dan $\mathrm{NH}_{3}$ lebih tinggi pada penambahan $5 \%$ minyak dibandingkan dengan kontrol. Populasi protozoa, protein mikroba, kecernaan bahan kering (KCBK), kecernaan bahan organik (KCBO) dan kecernaan serat kasar (KCSK) lebih rendah pada penambahan $5 \%$ minyak nabati dibandingkan dengan kontrol. Populasi protozoa menurun hingga 58,76\% pada R1; 66,89\% pada R2, dan 43,33\% pada R3. Dari hasil penelitian dapat diambil kesimpulan bahwa penambahan minyak nabati dapat menurunkan populasi protozoa, meningkatkan produksi VFA dan $\mathrm{NH}_{3}$. Penambahan minyak biji kapuk menghasilkan total VFA, produksi asetat, propionat, butirat dan $\mathrm{NH}_{3}$ tertinggi dibandingkan dengan perlakuan lainnya.

Kata kunci: fermentabilitas rumen, minyaknabati, kecernaan nutrien, in vitro

\section{Introduction}

Dairy cattle, especially during lactation, need high energy feed because they need two to three-fold nutrient supplies for body maintenance, milk synthesis, and post-partum tissue recovery (Khotijah et al., 2017). Fat is an important energy source for dairy cattle feed because it contains high calorie; fat energy is twice as much of carbohydrate or protein, and it produces lower heat increment (Wina and Susana, 2013; Diapari et al., 2017). Another benefit is for rumen defaunating agent. Fat can decrease protozoa population so that bacterial activity could increase the production of volatile fatty acid (VFA). Wibowo et al (2012) stated that up to $5 \%$ fat incorporated in ruminal diet did not interfere ruminal metabolism. However, high fatty feed would render biohydrogenation process in the rumen.

Vegetable oils from different source have different fatty acids composition (Titi and Fataftah, 2013) and is expected to produce different result in ruminal responses. Some vegetable oils for supplement in goat ration are 
corn oil, palm oil and kapok seed oil, with different fatty acids composition and market availability. Corn oil are easy to get and contains plenty unsaturated long chain fatty acids. The major fatty acids in corn oil is linoleic acids (C18:2) up to $53.99 \%$ (Giron et al., 2016). Palm oil is cheap and highly available and composed mainly of palmitic acid (C16) $32-37 \%$ and oleic acid (C18:1) 46.14\% (Sitoresmi et al., 2009). Kapok seed oil contains high unsaturated long chain fatty acids such as palmitic acid (C16) $23.62 \%$, oleic acid (C18:1) $24.30 \%$, and linoleic acid (C18:2) 43.68\% (Widiyanto et al., 2016).

According to Giron et al. (2016), supplementing $4 \%$ corn oil in the dairy cows increased milk production and milk fat concentration, decreased the VFA molar production without interfere the molar ratio of acetate, propionate ad butyrate. Supplementation of $5 \%$ palm oil increased the growth and efficiency of feed conversion in weaning lamb (Dutta et al., 2008). Meanwhile, kapok seed oil (up to 5\%) supplemented to sheep did not affect the cellulolytic enzyme activity in the rumen (Widiyanto et al., 2010).

Accordingly, it is important to investigate the effect of different vegetable oils on ruminal fermentability, nutrient digestibility and energy efficiency based on the fatty acids. This in vitro study aimed to examine the potency of vegetable oils (corn oil, palm oil and kapok seed oil) to provide energy for lactating goat diet to optimize the rumen fermentability and nutrient digestibility.

\section{Material and Methods}

\section{Feed preparation}

Feed was made of forage and concentrates in 40:60 ratio. Forage consisted of corn straw and Calliandra calothyrsus, while the concentrate was made of rice bran, pollard, cassava waste meal, soybean meal, and molasses. The rations were formulated with 65$69 \%$ Total Digestible Nutrient (TDN) and 14\% Crude Protein (CP). The ration treatments were $\mathrm{RO}=$ control (ration without supplemented oil), $\mathrm{R} 1=\mathrm{R} 0+5 \%$ corn oil, $\mathrm{R} 2=\mathrm{R} 0+5 \%$ palm oil, and $\mathrm{R} 3=\mathrm{RO}+5 \%$ kapok seed oil. Feed composition and nutrients contents of rations are presented in Table 1.

The evaluated parameters were rumen $\mathrm{pH}$, protozoa population, microbial protein, ammonia concentration, VFA, acetate/propionate ration, methane energy, efficiency of energy conversion, in vitro dry matter digestibility (IVDMD), organic matter digestibility (IVOMD), and crude fiber digestibility (IVCFD).

\section{Experimental procedures In vitro rumen fermentation}

The samples of each experimental feed were incubated in vitro with buffered rumen fluid mixture following the procedure by Tilley and Terry (1963). Rumen fluid was collected before morning feeding from a rumen fistulated Ettawah Crossbred goat fed on a diet of forage and concentrate mixture following the ration for in vitro substrate. The experiment was conducted in the Faculty of Animal and Agricultural Sciences, Diponegoro University, Semarang. Before use, rumen fluid was filtered using cheese cloth and placed in insulated flasks under anaerobic conditions. About $500 \mathrm{mg}$ feed was inserted into a fermentation tube, added with $40 \mathrm{ml}$ McDougall buffer solution, $10 \mathrm{ml}$ rumen fluid and shaken with $\mathrm{CO} 2$ for 30 seconds. The tube was sealed with a rubber cap and placed in a waterbath at $39^{\circ} \mathrm{C}$ for 4 hourfermentation. Afterwards, the rubber cap was opened, and the tube was placed in iced water. The fermentation fluid was drawn to analyze protozoa population, and the supernatant was sampled to analyze rumen $\mathrm{pH}$, microbial protein, and ammonia and VFA concentration. 
Table 1. Composition and Nutrient Contents of Rations

\begin{tabular}{|c|c|c|c|c|}
\hline \multirow{2}{*}{ Feed Stuffs (\% DM) } & \multicolumn{4}{|c|}{ Composition } \\
\hline & Ro & R1 & $\mathrm{R} 2$ & R3 \\
\hline Corn straw & 30 & 28 & 28 & 28 \\
\hline Calliandra calothyrsus & 10 & 10 & 10 & 10 \\
\hline Rice bran & 17 & 16 & 16 & 16 \\
\hline Pollard & 19 & 18 & 18 & 18 \\
\hline Cassava waste meal & 13 & 13 & 13 & 13 \\
\hline Soybean meal & 8 & 7 & 7 & 7 \\
\hline Molasses & 3 & 3 & 3 & 3 \\
\hline Corn oil & 0 & 5 & 0 & 0 \\
\hline Palm oil & 0 & 0 & 5 & 0 \\
\hline Kapok seed oil & 0 & 0 & 0 & 5 \\
\hline Total & 100 & 100 & 100 & 100 \\
\hline \multicolumn{5}{|l|}{ Nutrient contents (\%) } \\
\hline Ash & 10.28 & 10.03 & 10.03 & 10.03 \\
\hline Crude protein (CP) & 15.15 & 14.69 & 14.69 & 14.69 \\
\hline Crude fiber (CF) & 25.05 & 24.56 & 24.56 & 24.56 \\
\hline Ether extract $(\mathrm{EE})$ & 2.67 & 7.60 & 7.60 & 7.60 \\
\hline Nitrogen free extract (NFE) & 46.77 & 45.55 & 45.55 & 45.55 \\
\hline Total Digestible Nutrient (TDN) & 60.41 & 68.93 & 68.93 & 68.93 \\
\hline
\end{tabular}

R0 : controlled ration, R1 : R0 + 5\% corn oil, R2 : R0 + 55 palm oil, R3 : R0 + 5\% kapok seed oil.

Protozoa population was count using a counting chamber according to Ogimoto and Imai (1981). A total of $1 \mathrm{ml}$ methyl blue formal saline solution (MFS = formaldehyde $37 \%$, methyl blue, $\mathrm{NaCl}$ and aquadest) was added to $1 \mathrm{ml}$ of rumen fluid. The mixture was directly enumerated using a counting chamber under the microscope with 40-time magnification.

The fermentation fluid was centrifuged at $3000 \mathrm{rpm}$ for 15 minutes, and the supernatant was used to measure rumen $\mathrm{pH}$ using $\mathrm{pH}$ meter (ATC), analyses of microbial protein and ammonia concentration using a spectrophotometer, and individual VFA concentration using a Gas Chromatography. Methane gas emission and energy efficiency were calculated using a method by Orskov and Ryle (1990).

\section{Nutrient digestibility determination}

In vitro dry matter, organic matter and crude fiber digestibility were identified by inserting $500 \mathrm{mg}$ feed to the fermentation tube and then added with $40 \mathrm{ml}$ McDougall buffer solution, 10 $\mathrm{ml}$ rumen fluid, and shaken with $\mathrm{CO} 2$ for 30 seconds. The mixture was subsequently incubated for $48 \mathrm{~h}$, then centrifuged at 3000 rpm / 15 min and added with $50 \mathrm{ml}$ pepsin $\mathrm{HCl}$ solution. The mixture was further incubated for $48 \mathrm{~h}$, and filtered using a vacuum pump and Whatman no. 41 filter paper. The samples were used to determine IVDMD, IVOMD and IVCFD based on Tilley and Terry (1963).

\section{Data analysis}

The collected data were subject to analysis of variance (ANOVA) in a randomized block design. Any significant difference across treatments was further tested by Duncan test (Steel and Torrie, 1994).

\section{Results and Discussions}

\section{Ruminal Fermentability \\ pH}

The data on in vitro rumen fermentability are presented in Table 2. Supplementing 5\% vegetable oil did not affect rumen $\mathrm{pH}(\mathrm{P}>0.05)$. It showed that the treatments did not interfere the rumen fermentation process. According to Adeyemi et al. (2015), rumen $\mathrm{pH}$ is not affected by the increasing amount of $0 \%, 4 \%$ and $8 \%$ of mixed $20 \%$ palm oil and $80 \%$ canola oil. Supplementation up to $4 \%$ of mustard, groundnut, sunflower, sesame, soybean and 
rice bran oil with substrate concentrate and hay in 60:40 ratio did not affect rumen $\mathrm{pH}$ (Roy et al., 2017). Khotijah et al. (2017) stated that $6 \%$ supplementation of sunflower oil in a substrate containing 70:30 ratio of concentrate and Brachiaria humidicola did not affect the change in rumen $\mathrm{pH}$. Measurement of $\mathrm{pH}$ is an important factor for measuring the rumen health due to the sensitivity of cellulose bacterial on $\mathrm{pH}$ changes. Ruminal $\mathrm{pH}$ value rumen ranged from 6.86 to 6.99 which was still optimum for microbial growth. The optimal value of $\mathrm{pH}$ is in range 6.4-6.8 for supporting cellulolytic bacterial activity to digest the fiber content of feed (Khaing et al., 2016; Arief et al., 2016).

\section{Protozoa Population}

Protozoa population was significantly affected $(P<0.05)$ by $5 \%$ vegetable oils supplementation. The mean total protozoa decreased after the addition of corn oil, palm oil and kapok seed oil compared to control. Vegetable oil contains unsaturated long chain fatty acid that could inhibit protozoa growth. The fatty acid coated the protozoa's cell membrane which subsequently interfered lipolysis activity of protozoa and kill the protozoa (Tamminga and Doreau, 1991). Some studies also documented the depression in protozoa population by the addition of vegetable oil. According to Sitoresmi et al. (2009), total protozoa ranged from 23.82 to $30.16 \times 103 / \mathrm{ml}$ with the addition of coconut, palm and sunflower oil. Protozoa population also decreased by the addition of $6 \%$ sunflower oil (Khotijah et al., 2017). Supplementation of vegetable oil into the ration could decrease total protozoa and increase bacterial activity to produce VFA as an energy supply for ruminant (Dijkstra et al., 2000). Supplementation of palm oil (39.8\% palmitic acid and $46.14 \%$ oleic acid) was the most significant in decreasing total protozoa; however, the result was not significantly different from corn oil (containing $11.8 \%$ palmitic acid, $10.66 \%$ oleic acid and $53.99 \%$ linoleic acid) and kapok seed oil (containing $23.63 \%$ palmitic acid, $24.30 \%$ oleic acid and $43.68 \%$ linoleic acid). It showed that both saturated and unsaturated long chain fatty acids in the vegetable oil had the same effect in decreasing the protozoa numbers.

\section{Volatile Fatty Acid (VFA)}

The production of acetate, propionate, butyrate and total VFA in the rumen fluid was significantly affected $(\mathrm{P}<0.05)$ by the supplementation of vegetable oil. The highest production of acetate was in the supplementation of $5 \%$ kapok seed oil, followed by palm oil and corn oil; these results were significantly higher $(P<0.05)$ than those of the control. Similarly, Morsy et al. (2015) reporting a higher acetic acid when lactating goat ration was supplemented with sunflower oil and sunflower seed compared to control feed. The higher acetate may due to cellulolytic bacterial activity. Hungate (1966) stated that acetate production from ruminal fermentation of fibrous feed was affected by cellulolytic bacterial such as Ruminococcus, Butyrivibrio, and Bactroides. The highest production of propionate, butyrate and

Table 2. Fatty Acid Contents of Corn Oil, Palm Oil, and Kapok Seed Oil

\begin{tabular}{lccc}
\hline Fatty Acid (\%) & Corn Oil* & Palm Oil** & Kapok Seed Oil*** \\
\hline Lauric acid (C12:0) & - & 0.06 & - \\
Palmitic acid (C16:0) & 11.80 & 39.8 & 23.62 \\
Stearic acid (C18:0) & 5.18 & 4.4 & 2.38 \\
Oleic acid (C18:1) & 20.66 & 46.14 & 24.30 \\
Linoleic acid (C18:2) & 53.99 & 0.72 & 43.68 \\
Linolenic acid (C18:3) & 1.01 & - & 2.92 \\
\hline
\end{tabular}

Source: Giron et al. (2016)*, Sitoresmi et al. (2009) and Koushki et al. (2015)**, Widiyanto et al. (2016)*** 
Anis Muktiani et al/Animal Production. 21(1):22-29, 2019

Accredited by Kemenristek Dikti No 32a/E/KPT/2017. ISSN 1411-2027

Table 3. Effect of vegetable oil supplementation on ruminal fermentability

\begin{tabular}{|c|c|c|c|c|}
\hline Parameters & Control & Corn Oil & Palm Oil & Kapok S. Oil \\
\hline $\mathrm{pH}$ & $6.86 \pm 0.21$ & $6.94 \pm 0.10$ & $6.95 \pm 0.16$ & $6.99 \pm 0.10$ \\
\hline Protozoa $\left(\times 10^{3} / \mathrm{ml}\right)$ & $99.44 \pm 32.38^{a}$ & $40.83 \pm 15.27^{b}$ & $32.78 \pm 14.64^{b}$ & $56.11 \pm 18.63^{b}$ \\
\hline \multicolumn{5}{|l|}{ VFA (Mm) } \\
\hline Acetate & $46.88 \pm 5.52^{b}$ & $60.07 \pm 3.20^{a}$ & $61.10 \pm 6.28^{\mathrm{a}}$ & $68.82 \pm 7.58^{a}$ \\
\hline Propionate & $20.91 \pm 1.80^{b}$ & $22.82 \pm 1.55^{b}$ & $23.41 \pm 2.85^{b}$ & $27.44 \pm 3.72^{a}$ \\
\hline Butyrate & $19.73 \pm 3.92^{b}$ & $19.91 \pm 2.84^{b}$ & $17.28 \pm 2.33^{b}$ & $29.37 \pm 3.86^{a}$ \\
\hline A/P Ratio & $2.26 \pm 0.32$ & $2.64 \pm 0.23$ & $2.63 \pm 0.34$ & $2.52 \pm 0.25$ \\
\hline Total VFA & $87.51 \pm 8.23^{b}$ & $102.80 \pm 5.72^{b}$ & $101.78 \pm 9.02^{b}$ & $125.62 \pm 10.76^{a}$ \\
\hline Methane* & $28.08 \pm 4.45^{b}$ & $34.28 \pm 2.18^{b}$ & $33.33 \pm 3.24^{b}$ & $42.23 \pm 4.42^{\mathrm{a}}$ \\
\hline Energy efficiency (\%) & $77.19 \pm 1.01$ & $76.00 \pm 0.62$ & $75.97 \pm 0.93$ & $76.47 \pm 0.58$ \\
\hline $\mathrm{NH}_{3}(\mathrm{mg} / \mathrm{dl})$ & $19.69 \pm 0.39^{b}$ & $22.35 \pm 1.91^{\mathrm{ab}}$ & $20.23 \pm 1.71^{\mathrm{b}}$ & $24.97 \pm 2.30^{a}$ \\
\hline MicrobProt $(\mathrm{mg} / \mathrm{ml})$ & $12.01 \pm 1.97^{\mathrm{a}}$ & $10.11 \pm 1.87^{\mathrm{ab}}$ & $9.39 \pm 0.86^{a b}$ & $8.84 \pm 0.75^{b}$ \\
\hline IVDMD (\%) & $61.06 \pm 3.11^{\mathrm{a}}$ & $57.19 \pm 3.30^{\mathrm{b}}$ & $56.82 \pm 3.20^{b}$ & $57.18 \pm 1.83^{b}$ \\
\hline IVOMD (\%) & $62.16 \pm 3.31^{\mathrm{a}}$ & $56.34 \pm 2.88^{b}$ & $55.89 \pm 2.35^{b}$ & $55.81 \pm 1.14^{b}$ \\
\hline IVCFD (\%) & $74.46 \pm 3.04^{\mathrm{a}}$ & $45.74 \pm 8.08^{c}$ & $61.46 \pm 2.38^{b}$ & $48.76 \pm 6.89^{c}$ \\
\hline
\end{tabular}

Values with different superscripts in the same column indicate significant difference $(P<0.05)$

total VFA was in supplementation of $5 \%$ kapok seed oil, while $5 \%$ corn and palm oil were not different from control $(P>0.05)$. 5\% kapok seed oil produced the highest total VFA because of the accumulation of a higher acetate, propionate and butyrate than the other treatments. The acids accumulated because the unsaturated fatty acid in kapok seed oil endured lipolysis and biohydrogenation process, then fermented into VFA. Jarvis et al. (2009) stated that supplying vegetable oil into the ruminant ration would trigger lipolysis and biohydrogenation process, producing long chain fatty acids, glycerol, and galactose which would be fermented into acetate, propionate and butyrate.

The result showed that acetate/propionate $(A / P)$ ratio was not different $(P>0.05)$ across treatments. The $A / P$ ratio with the addition of vegetable oil ranged from 2.26 to 2.64 . The lower the $A / P$ ratio, the higher proportion of propionate. Accordingly, energy efficiency for metabolism also increased because the lipolysis process produced glycerol and transformed into propionate. Khaing et al. (2016) stated that propionate is the precursor of the gluconeogenesis process which could increase glucose synthesis as an energy source for ruminant. This result was lower than A/P ratio in supplementation of canola, sunflower and castor oil within 2.8 - 3.2 (Maia et al., 2012) or mixed canola and palm oil in a range of 2.71 3.61 (Adeyemi et al., 2015).

\section{Methane and Energy Efficiency}

The result showed that supplementation of $5 \%$ vegetable oil significantly affected $(P<0,05)$ methane production. Methane produced from ration $+5 \%$ kapok seed oil was the highest compared to corn oil, palm oil and control treatments because kapok seed oil helped produced higher acetate and butyrate. Martin et al. (2008) stated that production of acetate and butyrate trigger the formation of hydrogen (H2) that would be utilized by methanogenic bacterial to produce methane, hence methane accumulation was higher.

The efficiency of energy conversion (EEC) was not affected $(P>0,05)$ by the supplementation of vegetable oil. The EEC value, as well as the $A / P$ ratio in this study, was not different across treatments. The lower $A / P$ ratio reflected a higher efficiency of energy conversion from hexose to VFA. Rasmussen and 
Harisson (2011) stated that the lower A/P ratio indicated a higher efficiency of energy.

$\mathrm{NH}_{3}$

The mean concentration of $\mathrm{NH}_{3}$ was significantly affected $(\mathrm{P}<0.05)$ by the addition of vegetable oil. The highest concentration was obtained from the $5 \%$ kapok seed oil. The result of this study was higher (15.3 to $17.4 \mathrm{mg} / \mathrm{dl}$ ) than that of addition of canola, sunflower and castor oil (Maia et al., 2012) and in addition of blended palm oil and canola oil on $0-8 \%$ which ranged from $11.03-12.5 \mathrm{mg} / \mathrm{dl}$ (Adeyemi et al., 2015). Leng (1990) reported that $10-20 \mathrm{mg} / \mathrm{dl}$ $\mathrm{NH}_{3}$ was optimum to digest fibrous feed by rumen microbes. Furthermore, Mc Donald et al. (2002) stated that the optimum $\mathrm{NH}_{3}$ concentration for microbial protein synthesis was 6 - $21 \mathrm{mMol}$ or about $8.4-29.4 \mathrm{mg} / \mathrm{dl}$. The average value of $\mathrm{NH}_{3}$ in this study was $19.69-$ $24.97 \mathrm{mg} / \mathrm{dl}$, indicating a sufficient level for amino acids synthesis by rumen microbes.

\section{Microbial protein}

Microbial protein significantly decreased $(P<0.05)$ by the vegetable oil supplementation. The highest and lowest microbial protein in this study was found in the supplementation of corn oil $(10.11 \mathrm{mg} / \mathrm{ml})$ and kapok seed oil $(8.84$ $\mathrm{mg} / \mathrm{ml}$ ), respectively, due to fatty acids contained in the vegetable oil. Long chain fatty acids tend to inhibit the rumen microbes' growth, including bacteria and protozoa, which could depress microbial protein synthesis. In general, long chain fatty acids are detrimental to rumen microbial activity, and worse to protozoa (Dijkstra et al., 2000). The average microbial protein in this research was higher than $0.39-0.41 \mathrm{mg} / \mathrm{ml}$ produced by $7.5 \%$ supplementation of coconut oil, palm oil and sunflower seed oil supplementation (Sitoresmi et al., 2009) and $3.8-5.1 \mathrm{mg} / \mathrm{ml}$ from $3 \%$ soybean oil (H-L Mao et al., 2010). Supplementation of $5 \%$ corn oil, palm oil and kapok seed oil did not affect microbial protein and remained in normal range.
According to Orskov (1992), the precursors for microbial protein synthesis were carbon chain, energy and $\mathrm{NH}_{3}$. Carbon chain and energy could be obtained from VFA, while NH3 is the source for $N$. The optimum microbial protein production was obtained from 80-160

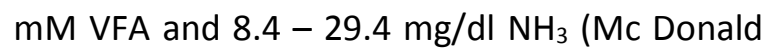
et al., 2002). This study showed that supplementation of $5 \%$ vegetable oil increased VFA to $125.42 \mathrm{mM}$ and $\mathrm{NH}_{3}$ to $24.97 \mathrm{mg} / \mathrm{dl}$; therefore, it was a viable precursor for microbial protein synthesis.

\section{In vitro digestibility of dry matter, organic matter and crude fiber}

The result of nutrient digestibility analysis is presented in Table 3. Vegetable oil supplementation significantly decreased $(\mathrm{P}<0.05)$ in vitro digestibility of dry matter (IVDMD) (56.82 to 61.06\%) and organic matter (IVOMD) (48.62 to $56.00 \%$ ). The declining digestibility may due to unsaturated fatty acids effect in the supplemented vegetable oil involving the cytotoxic effect of the unsaturated fatty acid with free carboxyl group. This compound could interfere the function of cell bio-membrane, such as the uptake of amino acids and protoplasmic energy metabolism. Another contributing factor was the depleting of the essential mineral availability for rumen microbe, because the fatty acid bond those elements (Widiyanto et al., 2007).

The result showed that IVCFD was significantly different $(P<0,05)$ across treatments. Supplementation of corn oil and kapok seed oil resulted in a lower IVCFD than that of palm oil and control because corn oil and kapok seed oil had a higher unsaturated long chain fatty acid (LCFA) than palm oil, namely $74.65 \%$ vs. $67.98 \%$ vs. $46.86 \%$ (long chain UFA), respectively. Vegetable oil rich in unsaturated LCFA would decrease more crude fiber digestibility. Dijkstra et al. (2000) stated that fiber degradation in the rumen was reduced when the amount of unsaturated LCFA 
in the diet was raised. This phenomenon could occur due to the inhibition of fibrolytic bacteria activity with the unsaturated LCFA. According to Messana et al. (2013), the unsaturated LCFA could inhibit fibrolytic bacteria activity, thereby reducing fiber digestibility.

\section{Conclusions}

Supplementation of $5 \%$ vegetable oil tend to decrease the nutrient digestibility without interfering the ruminal fermentability. Supplementation of 5\% kapok seed oil resulted in the highest total VFA and NH3 compared to corn oil and palm oil.

\section{References}

Adeyemi K. D., A. Q. Sazili, M. Ebrahimi, A.S. Samsudin, A. R. Alimon, R. Karim, A. A. Karsani, dan A. B Sabow. 2015. Effects of blend of canola oil and palm oil on nutrientintake and digestibility, growth performance, rumenfermentation and fatty acids in goats. Anim. Sci. J.87 (9) : 1137 - 1147.

Arief, N. Jamarun and B. Satria. 2016. Characteristics of Ettawa Crossbred Dairy Goat Rumen Fluid and Digestibility of Palm Oil Industry By-Products. Pak. J. Nutr., 15 (1) : $28-32$.

Diapari, D., W. Hermana, F. Prameswari, and A. Jayanegara. 2017. Physiological response and haemotological profile on reproductive ewe consuming diet supplemented with black tea extract and sunflower seed oil. Anim. Prod. 19 (3) : $143-150$.

Dijkstra, J., W.J.J. Gerrits, A. Bannink, and J. France. 2000. Modelling Lipid Metabolism in the Rumen. In :Modelling Nutrient Utilization in Farm Animals. (eds) J.. McNamara, J. France, and D.E.

Dutta, T.K., M. K. Agnihotri and S. B. N. Rao. 2008. Effect of supplemental palm oil on nutrient utilization, feeding economics and carcass characteristics in post-weaned Muzafarnagari lambs under feedlot condition. Small.Rum. Res. 78 (1-3) : 66-73.

Giron, J.E.P., M.L.P. Restrepo, and J.E.C. Fornaguera. 2016. Supplementation with corn oil and palm kernel oil to grazing cows :ruminal fermentation, milk yield, and fatty acid profile. R. Bras. Zootec., 45 (11) : $693-703$.

H,-L Mao, J-K Wang, Y-Y Zhou and J-X Liu. 2010. Effects of addition of tea saponins and soybean oil on methane production, fermentation and microbial population in the rumen of growing lambs. Livestock Sci 129 (2010) : 58 - 62.

Hungate, R. E. 1966. The Rumen and It's Microbes. Academic Press, New York.

Jarvis, G. N. and E. R. B. Moore. 2010. Lipid Metabolism and the Rumen Microbial Ecosystem. In : K. N. Timmis (ed.), Handbook of Hydrocarbon and Lipid Microbiology. SpringerVerlag Berlin Heidelberg. pp. 2245 - 2257.

Khaing, K.T., T.C. Loh, S. Ghizan, M. F. Jahromi, R.A. Halim, and A.A. Samsudin. 2016. Profiling Rumen Fermentation and Microbial Population Changes in Goats Fed with Napier Grass Supplemented with Whole Corn Plant Silage. Asian J. Anim. Sci., $10(1): 1-14$.

Khotijah, L., E.I. Pandiangan, D. A. Astuti, dan K. G. Wiryawan. 2017. Effect of sunflower oil supplementation as unsaturated fatty acid source on rumen fermentability and performance of lactating Garut ewes. J. Indon. Trop. Anim. Agric. 42 (3) : 185 - 193.

Koushki, M., M. Nahidi, and F. Ceraghali. 2015. Physic-chemical properties, fatty acid profile and nutrition in palm oil. J. Paramed. Sci. 6 (3) : 117 134.

Leng, R.A. 1990. Factors affecting the utilization of 'poor-quality' forages by ruminants particularly under tropical conditions.Nutr. Res. Rv. (3) : 277 $-303$.

Maia, M.O, I. Susin, E.M. Ferreira, C.P. Nolli, R.S. Gentil, A.V. Pirez and G.B. Mourao. 2012. Intake, nutrient apparent digestibility and ruminal constituents of sheep fed diets with canola, sunflower or castor oils. R. Bras. Zootec. 41 (11) : $2350-2356$.

Martin, C., M. Doreau, D. P. Morgavi. 2008. Methan mitigation in ruminants : from rumen microbes to the animal. Proceedings International conference Livestock and Global Climate Change 2008. Hammamet, Tunisia.

McDonald, P., R. A. Edwards and S.F.D. Greenhalgh. 2002. Animal Nutrition. Sixth Edition, New York.

Messana, J.D., T.T. Berchielli, P.B. Arcuri, R.A. Reis, R.C. Canesin, A.F. Ribeiro, G. Fiorentini, and J.J.R. Fernandes. 2013. Rumen fermentation and rumen microbes in Nellore steers receiving diets with different lipid contents. Rev. Bras. Zootec. 42 (3) : $204-212$.

Morsy, T.A., S. M. Kholif, A. E. Kholif, O. H. Matloup, A.Z.M. Salem and A. Abu Elella. 2015. Influence of Sunflower Whole seeds or oil on ruminal fermentation, milk production, composition, and fatty acid profile in lactating goats. Asian Australas. J. Anim. Sci. Vol 28 (8) : 1116 - 1122.

Ogimoto K and Imai S. 1981. Atlas of Rumen Microbiology.Tokyo : Japan Scientific Societies Press. 
Orskov, E. R. 1992. Protein nutrition in ruminant. 2nd Ed. Published by Academic Press Limited, London.

Orskov, E. R. and M. Ryle. 1990. Energy Nutrition in Ruminant. Elsevier Applied Science. London.

Rasmussen, J. and A. Harisson. 2011. The benefits of supplementary fat in feed rations for ruminants with particular focus on reducing levels of methane production. ISRN Veterinary Sciences Vol2011 : 1-10.

Roy, A., G. P. Mandal, and A. K. Patra. 2017. Effects of different vegetable oils on rumen fermentation and conjugated linoleic acid concentration in vitro. Vet. World 10 (1) : 11 16.

Sitoresmi, P. D., L. M. Yusiati, dan H. Hartadi. 2009. Pengaruh penambahan minyak kelapa, minyak biji bunga matahari, dan minyak kelapa sawit terhadap penurunan produksi metan di dalam rumen secara in vitro. Bul. Pet. Vol. 33 (2) : 96 105. (Abstract in English)

Steel, R. G. D dan J. H. Torrie. 1994. Prinsip dan Prosedur Statistika Suatu Pendekatan Biometrik. Cetakan kedua. Gramedia Pustaka Utama, Jakarta. (Diterjemahkan oleh B. Sumantri)

Tamminga, S. and M. Doreau. 1991. Lipids and rumen digestion. In : J. P. Jouany (Ed.) Rumen Microbial Metabolism and Ruminal Digestion. Pp. 151.INRA. Paris, France.

Tilley, J. M. A. and R. A. Terry. 1963. A two stage technique for the in vitro digestion of forage crops. J. Br. Grassl. Soc. (18) : $104-111$.

Titi, H. H. and A. A. Fataftah. 2013. Effect of supplementation with vegetable oil on performance of lactating Awassi ewes, growth of their lambs and on fatty acid profile of milk and blood of lambs. Arch. Tierz. $5645: 467$ - 479.

Wibowo, M.S., M. D. Efendi, S.D. Widyawati, Lutojo, J. Riyanto dan W.P.S. Suprayogi. 2012. Pengaruh suplementasi minyak ikan lemuru dan minyak kelapa sawit terproteksi dalam ransum terhadap performan dan kualitas kimia daging domba local jantan. J. Trop. Anim. Husb. 1 (1) : 67 - 74. (Abstract in English)

Widiyanto, M. Soejono, Z. Bachrudin, H. Hartadi, dan Surahmanto. 2007. Pengaruh suplementasi minyak biji kapok terproteksi terhadap daya guna pakan serat secara in vitro. J. Indon. Trop. Anim. Agric 32 (1) : 52 - 57. (Abstract in English)

Widiyanto, M. Soejono, Z. Bachruddin, H. Hartadi dan Surahmanto. 2010. The influence of kapok (Ceibapentandra) seed oil supplementation on cellulolytic enzyme and rumen microbial fermentation activity of local sheep. J. Indon. Trop. Anim. Agric. 35 (2) : $129-133$.

Widiyanto, Suranto, E. Kusumanti and Mulyono. 2016. The influence of protected kapok seed oil supplementation on in vitro ruminal fermentability and linoleic acid status with Etawah crossbred goat rumen fluid and elephant grass as feed. Afr. J. Agric Res. Vol 11 (14) : 1237 $-1244$.

Wina, E. dan I. W. R. Susana. 2013. Manfaat lemak terproteksi untuk meningkatkan produksi dan reproduksi ternak ruminansia. Wartazoa 23 (4) : 176 - 183. (Abstract in English) 